\title{
SALAT DALAM TRADISI ISLAM KEJAWEN
}

\author{
Samidi Khalim \\ Peneliti Bidang Lektur dan Kazanah Keagamaan \\ Balai Penelitian \& Pengembangan Agama Semarang
}

\begin{abstract}
Islam Kejawen here is meant as Islam as practiced in the Kingdom of Java. A reflection of Islam Kejawen can be seen in the works of literature written by the kingdom poets. This paper raises thoughts of Kraton Surakarta poet, Ngabehi Sastrawijaya, who lived during the reign of Paku Buwana III and Paku Buwana IV. The works of Sastrawijaya analyzed are Suluk Sajatining Salat and Suluk Salat Sarengat Tarekat Hakekat Makripat stored in the library of the Kingdom of Surakarta Museum, Museum Sasana Pustaka. This article analyzes the text to reveal both the meaning and function of the suluk for Islam Kejawen practice.
\end{abstract}

Key words: prayer, javan Islam, kingdom, tradition.

\section{Pendahuluan}

Islam Kejawen merupakan varian agama Islam yang dianut oleh orang-orang Jawa, khususnya Jawa Tengah yang berpusat di Solo dan Yogyakarta sebagai sentral budaya kraton Jawa. Islam Kejawen, atau disebut juga dengan Agami Jawi, menurut Koentjaraningrat adalah paham keagamaan perpaduan antara adat keagamaan asli Jawa (animismedinamisme) dengan agama Hindu-Budha dari jaman Majapahit dan pengaruh agama Islam dari jaman Demak (Koentjaraningrat 1984: 312; Hadikusuma 1993: 72). Panembahan Senopati (1588-1601 M), sebagai raja Mataram Islam pertama dapat dikatakan sebagai the founding father dari agama Islam Kejawen ini (Hadikusuma 1993: 68; Graaf dan Pigeaud 1989). Agama Islam Kejawen semakin berkembang seiring dengan kepercayaan masyarakat Jawa bahwa agama ageming aji, yakni agama yang dianut oleh rakyat berdasarkan agama yang dianut oleh rajanya. Secara historis, agama-agama yang masuk ke tanah Jawa dari Hindu, Budha, dan kemudian Islam, senantiasa bertumpu pada pusat pemerintahan (kerajaan). Agama yang dianut oleh raja menjadi agama resmi kerajaan yang harus diikuti oleh rakyatnya.

Panembahan Senopati sebagai perintis agama Islam Kejawen ini, setelah wafat digantikan oleh putranya, Sultan
Agung (1613-1645) yang nama aslinya Mas Rangsang dan setelah menjadi raja bergelar Panembahan Agung Senopati Ing Alogo Ngabdulrahman. Sultan Agung dikenal sangat alim dan dekat dengan kaum putihan atau santri dan ulama. Pada masa pemerintahan Sultan Agung inilah titik awal persentuhan budaya pesisiran dengan budaya pedalaman, atau akulturasi budaya Islam dari daerah pesisir dan budaya Hindu Jawa di daerah pedalaman (Hadikusuma 1993: 69). Persentuhan atau sinkretisme antara budaya pesisiran dan pedalaman inilah yang pada akhirnya melahirkan dan menyuburkan Kepustakaan Islam Kejawen (Simuh 1988: 2).

Menurut Simuh, Kepustakaan Islam Kejawen adalah salah satu kepustakaan Jawa yang memuat perpaduan antara tradisi Jawa dengan unsur-unsur ajaran Agama Islam (Simuh, 1988: 2). Kepustakaan ini menggunakan tulisan (huruf) dan bahasa Jawa, sedangkan isinya cenderung bernuansa mistik dan sedikit yang mengungkapkan permasalahan syariat Islam. Kepustakaan ini termasuk kategori kepustakaan Islam, karena banyak mengungkapkan ajaran-ajaran Islam, meskipun ada sebagian yang tidak menghargai aspek syariatnya, tetapi banyak juga yang dimanfaatkan oleh orang-orang Islam di Jawa sebagai sumber ajaran hidup. 
Istilah yang sering digunakan dalam kepustakaan Islam Kejawen untuk menyebut karya-karya sastra para pujangga Jawa adalah primbon, wirid, serat, dan suluk (Simuh 1988: 3). Wirid, serat, dan suluk memuat ajaran-ajaran tentang mistik Islam (tasawuf), sedangkan primbon berisi ramalan, doa, mantra, berbagai tradisi-ritual orang Jawa, dan sebagian kecil ajaran tentang syariat Islam. Tradisi pustaka Kejawen ini berkembang hingga beberapa generasi kerajaan Mataram Islam, yaitu sampai pada masa kraton Surakarta abad 19 dengan pujangga Penutupnya Raden Ngabehi Ranggawarsita (1802-1873). Pustaka Islam Kejawen di tangan para pujangga keraton yang ditopang oleh kekuasaan, membuat budaya mistik Jawa semakin kuat dan mengakar. Zaman Mataram Islam telah melahirkan pujanggapujangga besar di tanah Jawa, seperti Sultan Agung sendiri, Yasadipura I, Yasadipura II, Paku Buwana III, Paku Buwana IV, Mangkunegara IV, Ranggasutrasna, Sastradipura, Ranggawarsita (Yasadipura III), dan pujangga-pujangga Jawa lain.

Interpretasi orang Jawa terhadap ajaran agama, khususnya masalah ketuhanan, disajikan secara literal agar mudah dipahami dan diamalkan oleh masyarakat. Ajaran agama Islam yang masuk ke tanah Jawa, diterima oleh masyarakat, sering mengalami interpretasi yang berbeda dari sumbernya (al Qur'an dan al Hadits), sesuai dengan setting budaya dan pemikiran yang berkembang pada masanya. Interpretasi masyarakat Jawa atas ajaran Islam terlihat lebih dominan menonjolkan unsur-unsur budaya Jawanya, untuk mempertahankan citra "adiluhung" budaya Jawa (Khalim, 2008: 109). Penjawaan atau Jawanisasi ajaranajaran Islam tercermin dari maraknya karyakarya sastra para pujangga Jawa, baik itu pujangga kraton maupun para pengikutnya.

\section{Pujangga Kraton}

Sunan Paku Buwana III lahir pada tanggal 4 Februari 1732, memegang tampuk pemerintahan Kasunan Surakarta pada tahun 1749-1788 M (Nurhajarini,
1999:105). Beliau adalah pengganti Paku Buwana II yang memindahkan pusat pemerintahan dari Kartasura ke Surakarta pada tahun 1743, karena sedang berkecamuk konflik antar keluarga istana (De Graaf, 1984:264). Sunan Paku Buwana II lahir pada tahun $1711 \mathrm{M}$, dan memegang pemerintahan Kasunanan Surakarta pada tahun 1726-1749 M. Pada waktu itu sedang terjadi perang perebutan kekuasaan antar keluarga istana, yang diperburuk dengan adanya pemberontakan yang dilakukan oleh orang-orang Cina, yang kemudian dikenal dengan peristiwa "Geger Pacinan" tahun 1740 M (Nurhajarini dkk., 1999:69). Pada tahun 1740-1742 Sunan Paku Buwana II mengungsi ke Ponorogo dengan mengganti namanya menjadi Panembahan Brawijaya. Penggantian nama tersebut dengan maksud untuk menyelamatkan diri, menutup identitas dirinya, agar dianggap sebagai keturunan Sunan Lawu, Raden Guntur atau Raden gugur.

Kemelut kerajaan belum reda, karena kaum pemberontak Cina berkoalisi dengan Raden Mas Garendi yang bergelar Sunan Kuning atau Susuhunan Amangkurat Amral. Koalisi pemberontakan tersebut akhirnya menghancurkan istana-Kraton Kartasura, sehingga memaksa Paku Buwana II untuk memindahkan ibukotanya menuju ke Surakarta (17 Februari 1749). Kemudian pada tanggal 11 Desember 1749, Paku Buwana II menyerahkan kerajaan Mataram kepada VOC dengan perjanjian Het Allerbelangrijkste, yang artinya perjanjian yang paling penting (Graaf, 1984:264).

Pada masa Paku Buwana II dan Paku Buwana III terdapat barisan oposisi yang kuat, yaitu Pangeran Mangkubumi, yang melakukan perlawanan dari tahun 17461755 M. Konflik keluarga istana pada masa Paku Buwana II ini belum berakhir sampai masa pemerintahan digantikan oleh Paku Buwana III. Kemudian setelah PB III naik tahta menggantikan PB II, maka upayaupaya untuk mendamaikan konflik tersebut pun dilakukan. Ketegangan politik dan konflik keluarga kraton mereda berkat adanya Perjanjian Giyanti dan Salatiga (th 1757 M). Sebagai akibat dari perjanjian 
tersebut, maka pada masa pemerintahan Paku Buwana III ini terjadi proses sejarah Palihan Negari (pembagian negara), pembagian kraton menjadi dua wilayah, yaitu Kasunanan Surakarta dengan rajanya bergelar Paku Buwana (PB) dan Kasultanan Yogyakarta dengan rajanya bergelar Hamengku Buwana (HB) pada tahun 1755 M (Purwadi dkk., 2005:342).

Ketegangan politik dan konflik keluarga kraton yang mereda berkat adanya Perjanjian Giyanti dan Salatiga, membuat suasana pemerintahan Paku Buwana III semakin kondusif. Dalam suasana inilah yang kemudian membuat laju perkembangan sastra Jawa pada masa pemerintahan Paku Buwana III berkembang semakin pesat. Perkembangan tersebut tidak lepas dari peran dan dukungan istana, sebagai pusat budaya Jawa. Paku Buwana III disamping sebagai seorang raja juga ahli dalam olah sastra, hal ini terbukti dari karya-karyanya yang masih dapat dinikmati oleh generasi berikutnya. Kepandaian dan kemahiran Paku Buwana III dalam hal sastra dan budaya diwariskan juga kepada putranya, yaitu Sunan Bagus yang di kemudian hari memegang pemerintahan dengan gelar Paku Buwana IV (1788-1820 $\mathrm{M})$, yang kemudian menjadi pujangga ulung juga.

Paku Buwana III selama memegang tampuk pemerintahan sangat aktif mengembangkan sastra dan budaya, bahkan beliau termasuk penulis yang produktif, sehingga dapat dikatakan sebagai Pujangga ulung juga. Diantara karya-karya PB III adalah Serat Wiwaha Jarwa (th 1704 atau 1778 M), Suluk Bayan Maot, Suluk Sasmitaning Sanjata Cipta, dan juga Suluk Martabat Wahdat Wakidiyat ini. Selain itu PB III juga mengambil peranan dalam dunia kesenian, aktif dalam pelestarian tari-tari ritual kenegaraan, salah satunya adalah tari Bedhaya Ketawang, tari ritual kenegaraan yang diperagakan oleh sembilan penari putri, sampai sekarang masih tetap eksis. Produktifitas PB III tidak diragukan lagi, beliau yang menjabat sebagai seorang raja juga sangat mumpuni dalam dunia sastra dan budaya. Suasana pemerintahan yang kondusif membuat laju perkembangan sastra Jawa pada masa Paku Buwana III semakin pesat dengan memberikan perhatian yang intensif terhadap karya sastra dan budaya. Diantara langkahlangkah yang ditempuh oleh Paku Buwana III adalah dengan mengangkat beberapa orang pujangga istana, yaitu Pangeran Anih, Pangeran Wijil Kadilangu, Ngabehi Sastrawijaya, dan Kyai Ngabehi Yasadipura I (Purwadi, dkk., 2005:342).

Ngabehi Sastrawijaya dalam dunia kapujanggan kurang begitu dikenal, hanya diketahui bahwa dia berasal dari Kajoran, salah satu daerah di sebelah barat Magelang, Jawa Tengah. Gelar Pangeran yang disandangnya karena menjabat sebagai bupati di Kajoran, dan masih keturunan dari Pangeran Kajoran atau Panembahan Rama. Keluarga besar Kajoran ini merupakan keluarga ulama terkemuka, yang mempunyai pengaruh besar, dan memiliki hubungan perkawinan dengan Kraton Mataram.

Kapan persisnya Pangeran Sastrawijaya lahir dan sejak kapan dia menjalankan profesinya sebagai pujangga tidak ada sumber yang menyebutkan. Beberapa sumber hanya menyebutkan bahwa dia hidup pada masa Surakarta, pada masa pemerintahan paku Buwana II dan Paku Buwana III. Berdasarkan genealogi Dinasti Kraton Kartasura yang ditulis oleh Cristhoper Buyers dalam "The Kartasura Dynasty", Sastrawijaya masih keturunan dari Panembahan Seda Krapyak, yang meninggal di Batavia pada tahun 1743 $\mathrm{J}$ atau 1818 M (Buyers, http://www.4wd.net/royalark/Indonesia/Solo. $\mathrm{htm}$ ). Dalam silsilah dinasti Kraton Surakarta tersebut, Sastrawijaya adalah putra dari Raden Surangga Kusuma atau dikenal dengan Kanjeng Ngabehi Margataka. Raden Surangga ini putra sulung dari Pangeran Tumenggung Purba Kusuma, dan satu-satunya anak laki-laki dari kelima bersaudara. Adapun keempat adik perempuan Raden Surangga adalah Raden Ayu Surya Kusuma, Raden Ayu Purwa Kusuma, Raden Ayu Naya Kusuma, dan Raden Ayu Lurah Wirapati. 
Raden Tumenggung Purba Kusuma atau kakek Sastrawijaya adalah putra dari Pangeran Tumenggung Mataram atau Pangeran Purbaya IV yang menikah dengan salah seorang putri Raden Kajoran Ambalik atau Panembahan Rama. Pangeran Purbaya IV adalah putra dari Raden Mas Damar atau Adipati Purbaya yang menikah dengan putri kedua dari Pangeran Raden dari Kajoran dengan Raden Ajeng Wangsa Chipta (putri Panembahan Senopati ing Alaga Suta Wijaya Sayidin Panatagama-Panembahan Mataram). Raden Mas damar adalah putra dari Ingkang Sinuhun Kanjeng Susuhunan Adi Prabu Anyakrawati Senapati ing Alaga Sayidin Panatagama yang lebih dikenal dengan sebutan Panembahan Seda Krapyak atau Panembahan Mataram (16011613), dari istri ketiganya, yaitu seorang putri dari Giring.

Panembahan Seda Krapyak wafat pada pada tanggal 29 September 1613 dan dimakamkan di Kota Gede Yogyakarta, memiliki tiga orang istri, yaitu Ratu Tulung Ayu Putri dari Ponorogo, Ratu Alit putri dari Pajang, dan seorang putri dari Giring (tidak diketahui nama aslinya). Adapun dari pernikahannya dengan ketiga putri tersebut menurunkan beberapa anak, yaitu :

1. Ratu Tulung Ayu (istri I) menurunkan : Raden Mas Wurya atau Pangeran Arya Martapura dan Adipati Selarong.

2. Ratu Alit (istri II) hanya menurunkan seorang anak laki-laki, yaitu Raden Mas Jatmika atau Pangeran Mas Rangsang. Raden Mas Rangsang ini yang kemudian sukses melanjutkan kepemimpinan ayahnya, dengan gelar Ingkang Sinuhun Kanjeng Sultan Agung Senapati ing Alaga Prabu Pandita Chakra Kusuma AbdulRahman Sayidin Panatagama, Susuhunan Mataram. Raden Mas Rangsang ini yang kemudian lebih dikenal dengan Sultan Agung Anyakrakusuma (tahun 1613-1645), pada masa pemerintahannya ini Mataram mengalami masa kejayaan.

3. Putri Giring (istri III) ini juga hanya menurunkan seorang anak laki-laki saja, yaitu Raden Mas Damar atau Adipati Purbaya. Raden Mas Damar ini yang kemudian menikah dengan salah seorang putri dari Kajoran, yaitu Raden Ayu Purbaya (putri Pangeran Raden dengan Raden Ajeng Wangsa Ciptha). Dari Putri Giring inilah silsilah Pangeran Sastrawijaya.

Sebagai seorang keturunan bangsawan dan ulama dari Kajoran, Sastrawijaya mendapatkan pendidikan yang cukup. Sewaktu kecil Sastrawijaya pernah nyantri di pondok pesantren Kedu Bagelen bersama Kyai Yasadipura I, yang diasuh oleh Kyai Hanggamaya. Di pondok itulah dia mendapatkan berbagai ilmu pengetahuan, dari bahasa Arab, pengetahuan agama Islam dari fikih, akhlak, sampai tasawuf. Bukan hanya itu, bahkan di pondok ini pula dia sudah belajar olah batin, seperti tapa brata, kesaktian, ilmu kanuragan, dan samadi untuk mendekatkan diri kepada Tuhan. Selain materi-materi tersebut, di pondok itu pula Sastrawijaya juga mendapatkan pelajaran tentang kesusastraan baik Jawa klasik maupun Arab (Margapranata dalam Suhandjati, 2004: 3).

Sastrawijaya sebenarnya kurang banyak menghasilkan karya tulis, karena dia lebih banyak berkecimpung dalam dunia pemerintahannya yang pada waktu itu sedang mengalami konflik. Peran Sastrawijaya dalam mendamaikan konflik keluarga istana pada masa pemerintahan Paku Buwana II, sampai perpindahan istana Kartasura ke Surakata cukup beralasan untuk menghabiskan waktunya. Kemudian setelah konflik reda, diteruskan pada masa pemerintahan Paku Buwana III, maka dia mendapatkan kepercayaan untuk memimpin kadipaten Kajoran. Disela-sela kesibukannya sebagai seorang adipati itulah dia menuliskan beberapa serat, diantaranya adalah Suluk Sajatining Salat dan Suluk Salat Sarengat Tarekat Kakekat Makripat. Kedua suluk tersebut mencerminkan pemikiran Sastrawijaya yang pada satu sisi adalah sebagai seorang muslim yang taat, namun di sisi lain mencerminkan adanya jiwa orang Jawa 
yang begitu mengagungkan budaya kraton dan loyalitasnya kepada raja. Hal ini adalah wajar, mengingat bahwa Sastrawijaya adalah keturunan ulama-bangsawan, yang mendapat pendidikan di pondok pesantren dan juga pendidikan kapujanggan di lingkungan kraton.

Sebagai seorang adipati dan sekaligus sebagai seorang pujangga, Sastrawijaya tentunya tidak dapat lepas dari kepentingan politik kerajaan dalam menulis karya sastra. Sekalipun Sastrawijaya kurang begitu produktif dalam dunia sastra, karena lebih disibukkan oleh urusan kedinasan sebagai seorang adipati. Sekalipun sibuk dengan berbagai tugas negara, Sastrawijaya tetap teguh menjalankan salat, setidak-tidaknya salat dapat dikerjakannya dengan cara jama (mengumpulkan dua waktu salat). Dengan demikian dia dapat mengerjakan tugasnya sebagai seorang abdi negara dan juga sebagai seorang muslim yang taat. Ajaran salat didalam karyanya Suluk Sajatining Salat dan Suluk Salat Sarengat Tarekat Kakekat Makripat, setidak-tidaknya memberikan gambaran betapa dia adalah seorang muslim yang taat pada aturan agama (syariat). Oleh sebab itu karya-karya Sastrawijaya tersebut, cukup signifikan untuk dikaji pada saat ini. Mengingat masalah salat merupakan hal yang sangat urgen dalam kehidupan umat Islam, sehingga kita dapat mengambil pelajaran dan hikmah dari apa-apa yang pernah dikaji oleh para pendahulu kita, dan kita bisa mengetahui pola pemikiran pada masa itu. Kebudayaan dan peradaban suatu kaum dapat dilihat dari hasil-hasil pemikiran yang berkembang pada waktu itu. Sastra JawaIslam pada masa Surakarta sudah memberikan kontribusi yang cukup besar dalam mendakwahkan ajaran-ajaran Islam, sehingga Islam dapat diterima oleh semua lapisan masyarakat, baik itu dari kalangan priyayi maupun masyarakat jelata.

\section{3. "Kitab Suci" Orang Kejawen}

Karya sastra para pujangga Jawa yang memuat ajaran-ajaran agama, banyak yang tidak mengindahkan aspek syariat, bahkan seringkali mencampur adukkan berbagai ajaran agama. Islam dan unsur- unsur Jawa telah mengalami akulturasi (Partokusumo, 1995:222). Meskipun terjadi campur aduk berbagai macam ajaran agama, namun oleh sebagian masyarakat Jawa ajaran tersebut diklaim sebagai "sumber kebenaran" warisan para leluhur orang Jawa (Khalim, 2008: 110).

Karya sastra Islam Kejawen yang ditulis oleh para pujangga keraton, pada zaman Mataram Islam khususnya, semakin mengakar dihati masyarakat. Bagi sebagian masyarakat Jawa yang merasa memiliki budaya "adiluhung" dan mencoba melestarikan budaya tersebut, menganggap bahwa ajaran-ajaran para leluhur yang tertuang dalam naskah-naskah klasik sebagai "kitab suci" orang Jawa. Hal ini dapat kita lihat dari pakem (pedoman) ajaran Islam Kejawen dan munculnya aliran-aliran kebatinan yang muncul pada era sesudahnya banyak yang bersumber dari "kitab-kitab" (naskah klasik) karya sastra para pujangga keraton atau kalangan masyarakat penganutnya (Hadikusuma, 1993:72).

Meskipun hanya bersumber dari kitab-kitab karya para pujangga, yaitu pustaka Islam Kejawen, namun orangorang Islam kejawen sangat menjunjung tinggi nilai-nilai etika dan mengamalkan ajaran Islam pada umumnya. Syariat Islam, khususnya ibadah salat, puasa, dan haji, kadang-kadang memiliki makna dan interpretasi tersendiri bagi kalangan orang Islam kejawen. Salat yang merupakan ibadah harian, dalam kalangan orang Islam Kejawen menjadi rukun agama yang sangat penting. Salat tidak hanya sebatas rukun Islam dan media membersihkan diri dari dosa, tetapi juga sebagai jalan mistik untuk mencapai manunggaling kawula Gusti (Hariwijaya 2004:228).

Ajaran salat sebagai jalan mistik ini dapat kita temukan dalam berbagai serat atau suluk, diantaranya adalah Suluk Sajatining Salat dan Suluk Salat Sarengat Tarekat Kakekat Makripat yang ditulis oleh Abdi Dalem Pangeran Sastrawijaya dari Kajoran (w 1818). Sastrawijaya merupakan salah satu pujangga kraton pada masa pemerintahan Paku Buwana III (tahun 
1749-1788 M). Suasana pemerintahan yang kondusif membuat laju perkembangan sastra Jawa pada masa Paku Buwana III semakin pesat dengan memberikan perhatian yang intensif terhadap karya sastra dan budaya. Diantara langkahlangkah yang ditempuh oleh Paku Buwana III adalah dengan mengangkat beberapa orang pujangga istana, yaitu Pangeran Anih, Pangeran Wijil Kadilangu, Mas Ngabehi Sastrawijaya, dan Kyai Ngabehi Yasadipura I (Purwadi, dkk., 2005:342).

Ngabehi Sastrawijaya sebagai pujangga kraton memang kurang begitu dikenal, namun demikian masih terdapat beberapa karya sastra yang ditulisnya, diantaranya adalah Suluk Sajatining Salat dan Suluk Salat sarengat Tarekat Kakekat Makripat. Suluk Sajatinning Salat berbentuk tembang macapat dalam metrum Dhandhanggula, terdiri dari 10 pada (bait), berisi tentang esensi salat. Sedangkan Suluk Salat Sarengat Tarekat Kakekat Makripat terdiri dari 9 pada (bait), memberikan pengertian tentang tingkatan salat yang harus diamalkan oleh seorang muslim. Orang Islam Kejawen menjadikan salat tidak hanya sekedar gerakan badanlahiriah semata, tetapi membutuhkan penghayatan dan konsentrasi batin yang dapat menghantarkan seseorang mencapai Allah (manunggaling kawula-Gusti) (Khalim, 2010:67).

Suluk Sajatining Salat dan Suluk Salat Sarengat Tarekat Kakekat Makripat yang ditulis oleh Sastrawijaya merupakan bentuk interpretasi orang Jawa (pujangga Jawa-Islam) atas agama dan keyakinan yang dianutnya. Ajaran salat mengalami "Jawanisasi", diolah secara kejawaan, sesuai dengan kadar pengetahuan dan sosial budaya yang melingkupi, yaitu istana sentries. Dengan demikian, makna dan esensi salat yang sebenarnya bersumber dari al Qur'an dan al Hadits disesuaikan dengan tingkat pemahaman dan setting sosial budaya masyarakat Jawa pada masanya (Khalim, 2010:10).

\section{Makna dan Fungsi Salat}

Ibadah salat yang menjadi tiang agama Islam, memiliki makna dan interpretasi tersendiri bagi kalangan orang Islam kejawen. Salat bagi kalangan orang Islam Kejawen menjadi rukun agama yang sangat penting, tidak hanya sebatas rukun Islam dan media membersihkan diri dari dosa, tetapi juga sebagai jalan mistik untuk mencapai manunggaling kawula Gusti. Ajaran salat sebagai jalan mistik ini dapat kita temukan dalam berbagai serat atau suluk, diantaranya adalah Suluk Sajatining Salat dan Suluk Salat Sarengat Tarekat Kakekat Makripat yang ditulis oleh Abdi Dalem Pangeran Sastrawijaya dari Kajoran (w $1743 \mathrm{~J}$ atau $1818 \mathrm{M}$ ).

Suluk Sajatining Salat dan Suluk Salat sarengat Tarekat Kakekat Makripat. Suluk Sajatinning Salat berbentuk tembang macapat dalam metrum Dhandhanggula, terdiri dari 11 pada (bait), berisi tentang esensi salat. Sedangkan Suluk Salat Sarengat Tarekat Kakekat Makripat terdiri dari 9 pada (bait), memberikan pengertian tentang tingkatan salat yang harus diamalkan oleh seorang muslim. Orang Islam Kejawen menjadikan salat tidak hanya sekedar gerakan badan-lahiriah semata, tetapi membutuhkan penghayatan dan konsentrasi batin yang dapat menghantarkan seseorang mencapai Allah (manunggaling kawula-Gusti).

\subsection{Makna Salat}

Suluk Sajatining Salat dan Suluk Salat Sarengat Tarekat Kakekat Makripat yang ditulis oleh Sastrawijaya secara singkat memberikan gambaran tentang makna salat bagi orang-orang Islam Kejawen, yaitu salat sebagai ngelmu dan laku, dan makna simbolisme gerakan salat.

Salat sebagai ngelmu dan laku, oleh Sastrawijaya dilandaskan pada lafal niat salat (usalli), yang ditafsirkan secara falsafi untuk memperoleh makna terdalam (hakekat) dari kata-kata (lafal) niat sendiri. Kata Usalli sebagai lafal niyat salat, terdiri dari empat huruf (alif, sad, lam, dan ya atau alif layinah), oleh Sastrawijaya diartikan 
bahwa huruf Alif yang pertama merupakan perumpamaan manusia, dan huruf alif kedua merupakan perumpamaan Tuhan, yang menghimpit sifat dan zat Tuhan (huruf Sad dan Lam). Sifat dan Dzat Tuhan sebenarnya telah ada dan meyatu dalam diri manusia, sebagai sosok insan kamil (Khalim, 2010: 152).

Seorang salik jika sudah menempuh "ngelmu dan laku usalli," maka tahap berikutnya adalah "ngelmu dan laku muhamad". Lafal Muhamad terdiri dari huruf mim, ha, mim, dan dal, berpusat maknanya pada huruf mim itu sendiri. Jadi huruf mim itu merupakan intisari dari lafal Muhamad, yang berarti hakekat ilmu. Huruf mim ini keluar dari bersatunya antara hamba dan Tuhan, dalam usalli, karena ketika seseorang telah memahami ngelmu dan laku usalli, maka dia telah bersatu sifat dan zatnya dengan Allah. Hakekat ilmu itu ada di dalam hati, yaitu hati yang mulia yang tidak pernah mati, tidak terpisah dari Tuhan oleh kematian, hati inilah yang dinamakan dengan hati nurani. Hati nurani ini adalah hati yang mulia, pada hakekaktnya merupakan pancaran dari ruh Ilahi. Oleh sebab itu tidak pernah mati, tidak pernah berpisah dengan Allah (Khalim, 2010: 83)..

Muhammad itu menunjukkan adanya ilmu (batin/hakekat) yang yang harus dipahami dan diamalkan oleh manusia. Sebagaimana disebutkan pada bait berikut : "awasena sakawan punika, metu Muhkamad asale, murade emim iku, kang kakekat maring ing ngilmi, iku ati kang mulya". Muhamad bukan sekedar sosok manusia yang terlahir di Makah dan mencapai kejayaan kenabiannya di Madinah, tetapi dia merupakan warana (media) ilmu dari Allah SWT. "iku ati kang mulya, tan pisah puniku, tegese tan kena pejah, ati iku ing-aran ati nurani, iku ati kang mulya", di dalam diri Muhamad mengalir lautan ilmu yang tidak bertepi, ilmu yang bersumber dari Sang Pencipta dengan segala rahasianya. Ilmu tersebut hanya dapat dipahami dan diakses oleh orangorang yang mendalami olah rasa (batin). Rasa yang bersumber pada hati merupakan tempat keluarnya ilmu hakekat, ilmu yang diakses langsung dari Allah SWT. Hati merupakan tempat bersemayamnya ruh, ruh merupakan pancaraan Dzat Ilahi yang menyebabkan manusia hidup. Hati merupakan pancaran Dzat Ilahi, maka ia bersifat langgeng, tidak pernah mati. Oleh sebab itu, hanya dengan hati saja manusia dapat mengakses ilmu hakekat dari Ilahi (Khalim, 2010:84).

Hati sebagai warana menerima ilmu hakekat harus selalu dbersihkan. Salah satu alat membersihkan hati adalah dengan salat. Orang yang mampu menjadikan salat sebagai sarana bersih diri (jiwa), maka dia akan mampu mencapai derajat insan kamil, maqam makrifat. Dengan akhir perjalanan seorang salik tersebut, berarti dia telah berhasil mengenal dirinya sendiri dan mengenal hakekat Allah SWT. Dengan demikian salat dapat dijadikan sebagai sarana untuk bermakrifat (mengenal) Tuhan dalam arti yang sesungguhnya, yaitu mengenal Allah SWT dengan segenap zat, sifat, asma, dan af'al-Nya. Salat merupakan jalan mistik, sarana untuk mengenal Allah SWT, memperoleh pengetahuan langsung dari-Nya untuk dan menjadi manusia sempurna.

dan Selain makna salat sebagai ngelmu mengungkapkan makna salat berdasarkan symbol-simbol gerakan salat. Makna simbolisme gerakan-gerakan salat diinterpretasikan dari lafal niyat, gerakangerakannya (berdiri, ruku, sujud, duduk, dan salam), dan juga bacaan-bacaan di dalam salat (Khalim, 2010: 94-110). Semua interpretasi atas salat (baik itu bacaan atau gerakannya) cenderung menggunakan makna mistis, yang berpaham pada wahdat al wujud (manunggaling kawula-Gusti). Salat dipandang sebagai media seorang hamba untuk jumbuh atau bersatu dengan zat Ilahi.

Makna takbir ihram (takbirat al-ihram), yang mengandung arti "takbir yang mengharamkan", yakni mengharamkan segala tindakan dan tingkah laku yang tidak ada kaitannya dengan salat sebagai peristiwa menghadap Tuhan. Takbir pembukaan itu seakan suatu pernyataan formal seseorang membuka hubungan diri 
dengan Tuhan (hablum minallah), dan mengharamkan atau memutuskan diri dari semua bentuk hubungan dengan sesama manusia (hablum min al-nas). Maka makna instrinsik salat, disyaratkan dalam arti simbolik takbir pembukaan itu, yang melambangkan hubungan dengan Allah dan menghambakan diri kepada-Nya.

Berdiri sebagai salah satu rukun salat, menurut Sastrawijaya melambangkan bahwa Zat Allah Yang Maha Berdiri Sendiri (Qiyamuhu Binafsihi). Zat Allah yang tidak membutuhkan apa-apa, Dia ada karena zat-Nya sendiri, tidak melalui proses seperti makhluk. Oleh sebab itu ketika seseorang melakukan salat hendaknya sadar bahwa dirinya tengah menghadap zat Yang Maha Berdiri Sendiri, dan menginsyafi bahwa adanya dia karena adanya zat-Nya. Dengan penuh ketundukan dan kepasrahan dihadapan zat yang tidak mengalami kerusakan, zat yang tidak tunduk atau patuh kepada siapapun dan apapun.

Duduk tasyahud atau atakhiyat, akan memberikan kesadaran terhadap sang musalli untuk menginsyafi sepenuh hati, bahwa dia sedang berkomunikasi dengan Tuhan. Ketika duduk tasyahud, berarti dalam kesadaran mengabdikan diri dan menyerahkan seluruh hidupnya kepada Sang Pencipta. Sehingga makna salat betul-betul mengejawantah dalam kehidupan sehari-hari, karena seluruh syariat Islam yang dibawa oleh Nabi telah tercermin dalam salat, baik itu ketika sedang salat atau tidak.

Gerakan terakhir salat adalah Salam, diucapkan dengan menoleh ke kanan dan ke kiri. Menurut Sastrawijaya (Suluk Sajatining Salat bait 9-10), ketika mengucapkan salam ke arah kanan berarti kita menerima ucapan salam dari Allah Swt pada yaum al hisab kelak (hari perhitungan), sedangkan ucapan salam kekiri berarti jasmani menerima kasih sayang Allah pada hari tarik (kebangkitan).

Ucapan salam ke kanan berarti memberi salam kepada rohani pada hari misak, yang dimaksud adalah hari hisab (yaum al hisab : hari pembalasan), artinya orang yang melaksanakan salat besok pada hari pembalasan (yaum al hisab) akan mendapatkan taslim, rahmat atau kasih sayang Allah SWT. Sedangkan salam ke kiri, maknanya adalah jasmani memperoleh taslim dan rahmat atau kasih sayang Allah pada hari tarik (yaum al tarikh : hari kebangkitan), ketika bangun di padang mahsyar dan mendapati Zat Ilahi.

\subsection{Fungsi Salat}

Berdasarkan Suluk Sajatining Salat dan Suluk Salat Sarengat Tarekat Kakekat Makripat, salat berfungsi tidak hanya sebatas sebagai kewajiban (normative) seorang muslim, tetapi salat berfungsi sebagai "sarana bersih diri" dan "salat sebagai jalan mengenal diri dan Tuhan" (Khalim, 2010: 153). Seorang hamba harus menjalankan salat tidak hanya sebatas syariat saja, tetapi harus benar-benar diamalkan dan dihayati sampai menyatu dengan Tuhan.

Fungsi salat sebagai sarana bersih diri, artinya salat dapat menjadikan seseorang berbudi pekerti luhur, dan menyempurnakan akhlak sebagai sempurnanya syariat seseorang. Perilaku seorang musalli menjadi baik, menunjukkan bahwa dia telah merasakan kehadiran Allah di dalam hidupnya, budi pekerti luhur yang telah menjadi kebiasaannya merupakan anugerah, sebagai pertanda af'al-Nya. Zat Tuhan akan nampak nyata dalam perilaku atau sifat sehari-hari sang musalli, karena pada hakekatnya zat itu ada pada sifat. Sifat dan zat itu merupakan satu kesatuan yang tidak dapat dipisahkan, laksana api dengan panasnya atau es dengan dinginnya. Oleh sebab itu orang yang megerjakan salat dengan dengan benar, penuh keyakinan dan penghayatan akan benar-benar mencapai tujuan akhir salat tersebut, yaitu Allah SWT hadir dalam kehidupannya (Khalim, 2010: 117-118).

Salat menjadi sarana bersih diri yang dapat menghantarkan seseorang (musalli) semakin akrab dengan Allah SWT, bahkan merasakan persatuan dengan-Nya (manunggaling kawula-Gusti). Persatuan 
dengan Tuhan (manunggaling kawulaGusti) merupakan tujuan akhir dari mistik Islam kejawen, karena orang yang telah berhasil mengenal Tuhan (makrifat) akan menjadi manusia sempurna, derajat Insan Kamil. Derajat insan kamil inilah yang dipandang sebagai puncak mistik, derajat tertinggi para pejalan mistik. Salah satu cara untuk mencapai derajat insan kamil adalah dengan mengilmui, mengamalkan, menghayati, dan melanggengkan salat. Salat menjadi jalan mistik yang dapat menghantarkan sang musalli merasakan persatuan dengan Yang Mutlak, yaitu salat yang dikerjakan secara sempurna. Menurut Sastrawijaya, untuk mengerjakan salat dengan sempurna harus melalui beberapa tingkatan, yaitu : Salat Jumungah, Salat Kajat, Salat Daim, dan Salat Ismungalam. Pertama, Salat Jumungah, yaitu salat yang dikerjakan dengan segenap anggota ragawi (badan) yang sesuai aturan-aturan syariat, jenis atau tingkatan salat ini disebut dengan "sembah raga". Jenis atau tingkatan salat yang kedua disebut dengan Salat Kajat, yaitu salat yang dikerjakan dengan menggunakan tyas (hati), sehingga disebut dengan "Sembah Tyas". Ketiga Salat Daim, yaitu salat yang dikerjakan dengan menggunakan roh, sehingga disebut sebagai "Sembah Roh". Dan yang keempat adalah Salat Ismungalam, yaitu salat yang dikerjakan dengan menggunakan rasa, sehingga tahapan ini disebut dengan "Sembah Rasa". Keempat macam atau tingkatan salat ini disamakan dengan pemahaman tentang kesempurnaan iman seseorang, yaitu tingkat syariat, tarekat, hakekat, dan makrifat (Khalim, 2010: 123127).

Manusia yang ingin mengetahui hakekat Tuhan, maka harus bercermin di dalam dirinya, karena dengan mengenal diri sendiri berarti dia akan mengenal Tuhannya. Yang dimaksud mengenal diri disini berarti, kita harus memahami eksistensi jiwa-insaniah yang merupakan percikan dari zat Tuhan. Melalui konsep sembahnya (salat sarengat, salat tarekat, salat kakekat, dan salat makripat), Sastrawijaya memberikan gambaran bahwa didalam setiap stage tersebut terdapat rahasia-rahasia llahi yang dapat kita tangkap, sebagai jalan mengenal diri untuk mencapai penghayatan akan realitas Tuhan. Di dalam salat sarengat (sembah raga) yang menggunakan seperangkat fisik untuk menyembah, salat Tarekat dengan menggunakan alat sembah tyas (hati), dan Salat Kakekat menggunakan alat sembah ruh, dan pada salat Makrifat ini mengerahkan ketiga aspek alat sembah tersebut yang menjadi satu dalam rasa, untuk menghayati alam semesta sebagai satu kesatuan makhluk dengan Khaliqnya. Pada tahapan makrifat inilah kematangan ruhaniah salik telah mencapai puncaknya, sehingga tidak ada lagi rasa was-was atau ragu manunggalnya (kehendak dirinya) dengan kehendak Tuhan. Pada saat mencapai puncak makrifat, maka sudah terbuka tirai atau hijab antara sang salik dengan Tuhannya, sehingga ruhaninya benar-benar matang dan mampu mengendalikan segenap aspek perilaku raga dan jiwanya.

Penjelasan Sastrawijaya tentang konsep mengenal Tuhan (makrifat), yang dapat ditempuh oleh salik melalui stagestation ruhani (sembah raga, sembah tyas, sembah ruh, dan sembah rasa), jika dibandingkan dengan ajaran musyahadahnya Al Qusyairi, yaitu bahwa manusia itu mampu melihat Allah dengan mata hatinya, maka akan terlihat adanya titik persamaan. Menurut Al Qusyairi, bahwa di dalam hati manusia itu terdapat 3 alat yang dapat digunakan untuk musyahadah (menyaksikan) Allah, yaitu : al sirr, al ruh, dan al qalb. Al sirri digunakan untuk menyaksikan atau melihat Allah, al ruh digunakan untuk mencintai (mahabbah) kepada Allah, dan al Qalb digunakan untuk menangkap ilmu pengetahuan dari Allah SWT (Moh. Ardani, 1995:99-100). Al qalb sebagai alat untuk menangkap ilmu dari Allah SWT, sehingga tidak heran jika bagi orang-orang tertentu (yang telah mencapai derajat makrifat) mampu membaca hal-hal yang belum terjadi (weruh sadurunge winarah), melihat catatan Tuhan di lauh mahfudz. Dan ilmu inilah yang di kalangan orang-arang Jawa (Kejawen) dikatakan sebagai "ilmu sejati", karena diperoleh langsung dari "guru sejati", yaitu hati nurani. Menurut Sastrawijaya (dalam Suluk 
Sajatining Salat :5), hati nurani yang menjadi warana (media) bagi Allah untuk mengajarkan segala ilmu, segala rahasia kepada hamba-Nya. IImu yang diperoleh langsung dari Allah di dalam hati sanubari, atau ada juga yang menyebutnya dengan ilmu laduni. Perolehan "ilmu sejati" yang langsung disadur dari sisi Allah Swt, sebagaimana yang pernah dialami para nabi dan rasul, demikian juga dengan para wali-wali Allah.

Konsep salat Sastrawijaya ini sama seperti ajaran Mangkunegara IV dalam Serat Wedatama. Dalam serat tersebut, Mangku Negara IV mengajarkan bahwa untuk mencapai derajat tertinggi seorang hamba (insan kamil), maka seseorang harus menempuh empat tingkatan laku, yaitu sembah raga, sembah cipta, sembah jiwa, dan sembah rasa (Ardani, 1995:56). Konsep tersebut jika diperbandingkan dengan konsep tasawuf, yakni syariat, tarekat, hakekat, dan makrifat, memiliki kesamaan dalam bentuk dan urutan. Keempat macam sembah atau tingkatan tersebut merupakan mata rantai yang utuh, yang harus dikerjakan secara bertahap, sehingga pada ujungnya akan mencapai hakikat tujuan sembah itu sendiri, yaitu manunggaling kawula-Gusti (Khalim, 2010:122).

\section{Penutup}

Sastrawijaya sebagai pujangga kraton (pada masa Paku Buwana III) tidak dapat lepas dari budaya dan tradisi yang melingkupinya, bahkan kebijakan atau tata aturan yang berlaku di dalamnya. Kraton sebagai suatu entitas dan institusi mempunyai kebudayaan tersendiri, karena budaya Jawa bersifat istana sentris. Sastrawijaya yang memadukan antara tradisi Kejawen dengan unsur-unsur ajaran Islam dalam karya-karyanya, yang memperlihatkan corak pemikiran sinkretis seorang intelektual muslim-Jawa. Jenis kepustakaan yang dilahirkan dari tradisi besar kraton Jawa, berisikan unsur-unsur Islam dan Jawa dalam perkembangannya disebut dengan Islam Kejawen. Ajaran di dalam kepustakaan Islam Kejawen memang tidak sepenuhnya sesuai dengan tuntunan al Qur'an dan al Hadits, tetapi telah berjasa dalam memperkenalkan nilainilai ajaran kerohanian dan etika Islam kepada para pembaca sastra Jawa.

Oleh sebab itu karya sastra para pujangga Jawa-Islam, khususnya Pangeran Sastrawijaya, perlu diangkat sebagai bahan kajian dan penelitian lebih lanjut. Karya sastra yang dihasilkan para pujangga Jawa dapat direfleksikan sebagai hasil sejarah perjalanan pemikiran manusia dari masamasa sebelumnya, yang telah ikut berperan mendakwahkan Islam kepada umat pada masanya. Selain itu, karya Sastrawijaya juga memberikan gambaran tentang adanya "benang merah" dengan karyakarya sastra para pujangga Jawa lainnya, terutama hal-hal yang berkenaan dengan ajaran Tasawuf (spiritualitas Islam).

Menjadi tugas para generasi peneruskita semua, untuk melanjutkan perjuangan beliau (para pujangga) dalam mendakwahkan Islam melalui dunia pena. Tidak selamanya karya para pujangga Jawa itu bertentangan atau menyimpang dari al Qur'an dan al Hadits, demikian juga dengan pemikiran Sastrawijaya ini, tetapi tidak semuanya juga benar, karena masih adanya kepentingan-kepentingan politis para penguasa pada zamannya. Raja atau kerajaan sangat berperan dalam menjaga tradisi dan budaya, apalagi dalam menjaga wibawa dan kekuasaannya, sehingga tidak mustahil karya sastra yang dihasilkan oleh pujangga sebagai tangan panjang raja bermuatan politis.

\section{Daftar Pustaka}

Ardani, Moh. 1995. Al Qur'an dan Sufisme Mangkunegara IV (Studi Seratserat Piwulang), Jakarta: PT Dana Bhakti Wakaf.

De Graaf, H.J. dan Pigeud, TH. 1989. Kerajaan-kerajaan Islam di Jawa. Jakarta: Graffiti Pers, cetakan III.

Florida, Nancy K. 2000. Javanese Literature in Surakarta Manuscripts, Jilid I, SEAP Ithaca: Cornell University. 
Hariwijaya, M. 2004. Islam Kejawen. Yogyakarta: Gelombang Pasang.

Khalim, Samidi. 2008. Islam dan Spiritualitas Jawa. Semarang: Rasail.

2010. Salat Islam Kejawen. Semarang: Primamedia Press.

Koentjaraningrat. 1984. Kebudayaan Jawa, Jakarta: PN Balai Pustaka.

Margana, S. 2004. Pujangga Jawa dan Bayang-bayang Kolonial. Yogyakarta: Pustaka Pelajar.

Muljana, Slamet. 2006. Runtuhnya Kerajaan Hindu-Jawa dan Timbulnya Negara-negara Islam di Nusantara. Yogyakarta: LKiS, Cetakan III.

Partokusumo, Karkono Kamajaya. 1995. Kebudayaan Jawa Perpaduannya dengan Islam. Yogyakarta: IKAPI.

Poerbatjaraka dan Tarjan Hadijaya. 1952. Kepustakaan Jawa. Jakarta: Djambatan.

Purwadi, dkk. 2005. Ensiklopedi Kebudayaan Jawa. Yogyakarta: Bina Media.
Sastrawijaya, t.t. Suluk Sajatining Salat. Surakarta: Museum Sasono Pustaka.

. t.t. Suluk Salat Sarengat Tarekat Kakekat Makripat. Surakarta: Museum Sasono Pustaka.

Simuh. 1988. Mistik Islam Kejawen Raden Ngabehi Ranggawarsita. Jakarta: UI-Press.

. 1996. Sufisme Jawa. Yogyakarta: Bentang Budaya.

Suhandjati, Sri. 2004. ljtihad Progresif Yasadipura II dalam Akulturasi Islam dengan Budaya Jawa. Yogyakarta: Gama Media.

Sukardi (Ed.). 2001. Salat dalam Perspektif Sufi. Bandung: Rosdakarya.

Winarti, Sri. 2004. Sekilas Sejarah Karaton Surakarta. Surakarta: Cendrawasih.

\section{Website:}

Buyers, Cristhoper, The Kartasura Dinasty, http://www.4dw.net/royalark/Indonesia Solo. htm. Diunduh 19 April 2008.http://www.tembi.org/Mataram/matara m 01 .net. 